\title{
Becoming a pharmacist: the role of curriculum in professional identity formation
}

Christy NOBLE, Ian COOMBES, Paul Nicholas SHAW, Lisa M. NISSEN, Alexandra CLAVARINO.

Received (first version): 27-Oct-2013

Accepted: 2-Feb-2014

\begin{abstract}
*
Objective: To understand how the formal curriculum experience of an Australian undergraduate pharmacy program supports students' professional identity formation. Methods: A qualitative ethnographic study was conducted over four weeks using participant observation and examined the 'typical' student experience from the perspective of a pharmacist. A one-week period of observation was undertaken with each of the four year groups (that is, for years one to four) comprising the undergraduate curriculum. Data were collected through observation of the formal curriculum experience using field notes, a reflective journal and informal interviews with 38 pharmacy students. Data were analyzed thematically using an a priori analytical framework.

Results: Our findings showed that the observed curriculum was a conventional curricular experience which focused on the provision of technical knowledge and provided some opportunities for practical engagement. There were some opportunities for students to imagine themselves as pharmacists, for example, when the lecture content related to practice or teaching staff described their approach to practice problems. However, there were limited opportunities for students to observe pharmacist role models, experiment with being a pharmacist or evaluate their professional identities. While curricular learning activities were available for students to develop as pharmacists e.g. patient counseling, there was no contact with patients and pharmacist academic staff tended to role model as educators with little evidence of their pharmacist selves.

Conclusion: These findings suggest that the current conventional approach to the curriculum design may not be fully enabling learning experiences which support students in successfully negotiating their professional identities. Instead it appeared to reinforce their identities as students with a naïve understanding of professional practice, making their future transition to professional practice challenging
\end{abstract}

Keywords: Students, Pharmacy; Professional Practice Professional Role; Curriculum; Program Development; Qualitative Research; Australia

\footnotetext{
Christy NOBLE. MEd., Principal Medical Education Officer, Medical Education Unit, Gold Coast University Hospital. Southport, \& School of Pharmacy, The University of Queensland. Sta. Lucia, Qld (Australia).

Christy.noble@uqconnect.edu.au

Ian COOMBES. PhD. School of Pharmacy, The University of Queensland, Sta. Lucia, Qld (Australia). ian coombes@health.qld.gov.au

Paul Nicholas SHAW. PhD. School of Pharmacy, The University of Queensland, Sta. Lucia, Qld (Australia). nshaw@pharmacy.uq.edu.au

Lisa M. NISSEN. PhD. School of Pharmacy, The University of Queensland, Sta. Lucia \& School of Clinical Sciences, Queensland University of Technology, Brisbane Qld (Australia). I.nissen@qut.edu.au

Alexandra CLAVARINO. PhD. School of Pharmacy, The University of Queensland, Sta. Lucia, Qld (Australia). a.clavarino@sph.uq.edu.au
}

\section{INTRODUCTION}

The formation of students' professional identities is important for enabling the transition between university and working life. ${ }^{1,2}$ Strong professional identities assist novices to cope with uncertainty, builds confidence and at the same time provides a framework for professional work. ${ }^{3}$ Whilst measures have been implemented into pharmacy education to support the transition, there is limited evidence that professional identity formation has been a primary concern in pharmacist education.

Supporting the professional identity formation of pharmacy students is particularly important because of the evolving nature of professional practice. That is, the profession is increasingly becoming patientcentred in its focus and pharmacists are claiming responsibility for patient-outcomes as they relate to medicines. The characteristics and functions of 'modern' pharmacists are described as: caregiver, decision-maker, communicator, manager, life-long learner, teacher, leader and researcher. ${ }^{4}$ Despite this description, in reality pharmacists often see themselves in several ways, ranging from the clinical practitioner to the business-person and this can be confusing for students constructing their professional identities. ${ }^{5,6}$

As a result, despite making curriculum changes to support the development of patient-centred pharmacists, there are a number of studies which suggest that graduates are unable (or find it difficult) to enact patient-centred ways of being a pharmacist. $^{7,8}$ Health professional education (including medicine and nursing) and other professions (e.g. teaching) now see professional identity formation as a major goal. ${ }^{3,9-12}$ While these professions $^{3,9-12}$ have begun to explore students' professional identity formation through their curricular experience, information about pharmacy students' professional identity formation during their education is limited.

\section{Student Professional Identity Formation}

Professional identities are constructed through an "evolutionary and iterative process" resulting in an individual developing a "sense of a professional self". ${ }^{13}$ Professional identities are dynamic and change over time in response to an interplay between internal factors for example, emotion, motivation, claims we make about who we are, and external factors: that is, how situations and society recognises us such as in work contexts, interactions with peers and resultant experiences. ${ }^{13,14}$ The interplay between these factors can build and 
sustain professional identities or can result in the formation of naïve professional identities.

In professional education programs the key factors influencing students' professional identity formation include opportunities for imagination, observation, experiment and evaluation. ${ }^{1,15,16}$ That is, being able to imagine what it might be like to be a pharmacist, through learning activities where connections are made between what is being learnt and future practice. ${ }^{17}$ Opportunities to observe role models in action, either in practice or approximations of practice, are also needed for professional identity formation. Academics and tutors are often seen as key role models for professional education students $^{1,10}$ including pharmacists. ${ }^{18}$

Successful formation of professional identities also requires opportunities for students to experiment, that is, to try out what it might be like to be a pharmacist through engagement in practice or in activities which are realistic approximations of practice. ${ }^{1,15,16}$ These experiences can be fostered through authentic learning opportunities. ${ }^{19,20}$ For example, science students' engagement in authentic laboratory activities was found to promote their professional identity formation as scientists. ${ }^{21}$

Opportunities are also needed to allow students to evaluate their learning experiences. ${ }^{1,15}$ The process of evaluation is both internal, that is, claiming or disclaiming a professional identity based on internal standards and external, for example, feedback to students from other practitioners or educators on their performance as pharmacists. ${ }^{22}$

\section{Theory of social learning}

Sociocultural learning theory provided a sound theoretical framework for this study to understand how the formal pharmacy curriculum experience supports students' professional identity formation. $^{3,16,23,24}$ Learning, itself is a social and contextual experience, and results from an integration of meaning, practice, community and identity. ${ }^{16}$ Learning can be characterised by four interconnected components: 1) Meaning - that is, learning as experience; 2) Practice - that is, learning as doing; 3) Community - that is, learning as belonging and 4) Identity - that is, learning as becoming.

From this perspective, for curriculum design and experience to support identity formation, the key considerations are that students have the opportunity to actively participate in meaningful activities and are supported and guided by experts, within a community of practice. There should be opportunities for student engagement, as well as learning resources and activities which enable students to perceive themselves as pharmacists and to experience the effects of their actions as pharmacists. $^{16}$

There is an absence of studies examining pharmacy student professional identity formation in the context of higher education. Using an ethnographic approach, this study examined the student experience of the formal pharmacy curriculum at one Australian University and identified what learning opportunities exist for enabling pharmacy students to develop their identities as pharmacists.

\section{Context of the Study}

In Australia, before becoming registered pharmacists, students commonly complete a fouryear Bachelor of Pharmacy degree and then participate in an approved one-year intern-training program. ${ }^{25}$ The curriculum described in this study is typical of a number of pharmacy degrees across Australia. ${ }^{26}$ The curriculum content and structure are influenced by a range of factors; these include the necessity of complying with the Accreditation Standards as defined by the Australian Pharmacy Council $^{25}$ and working within the funding constraints of the university funding policy for pharmacy programs. $^{27}$

The four-year Bachelor of Pharmacy, examined in this study, commences with a combination of basic sciences and pharmacy specific subjects. As the students progress through the program the subjects become increasingly pharmacy specific and this learning is supported with experiential placements, which vary from two hours per week (first year) to four-week full time placements (fourth year), primarily in community pharmacies. There are six streams - quality use of medicines (QUM), social and professional aspects of pharmacy, drug discovery, dosage form design, biological fate of drugs and data analysis in pharmacy. These streams are consistent across the year groups from second year to fourth year and are described as being vertically and horizontally integrated. The main form of assessment is written theory examinations and these tend to comprise multiple choice and short answer questions. ${ }^{28}$ Other assessment activities include laboratory reports, essays and practical examinations such as objective structured clinical examinations.

\section{METHODS}

A four-week ethnographic study was conducted in a large, research focussed, Australian university in April/May 2010. The study was designed to examine a 'typical' week for a pharmacy student in each of the four year groups. Before commencing the study the semester timetables were examined and the following exclusion criteria and reasoning were used to ensure the week examined was 'typical':

- Not the first week of semester as this tends to be introductory lectures and overviews of the assessment requirements

- Not the weeks before mid- and end- of semester as these tend to include examination assessments and/or provide details about the requirements for these

- Not during event weeks such as 'rural week' or during experiential placements

Also, the contact times of lectures and tutorials were reviewed to ensure that they were consistent with the average weekly hours as per the university policy. We defined 'typical' as a week in the middle 


\section{Enter the field: 4 week observational study}

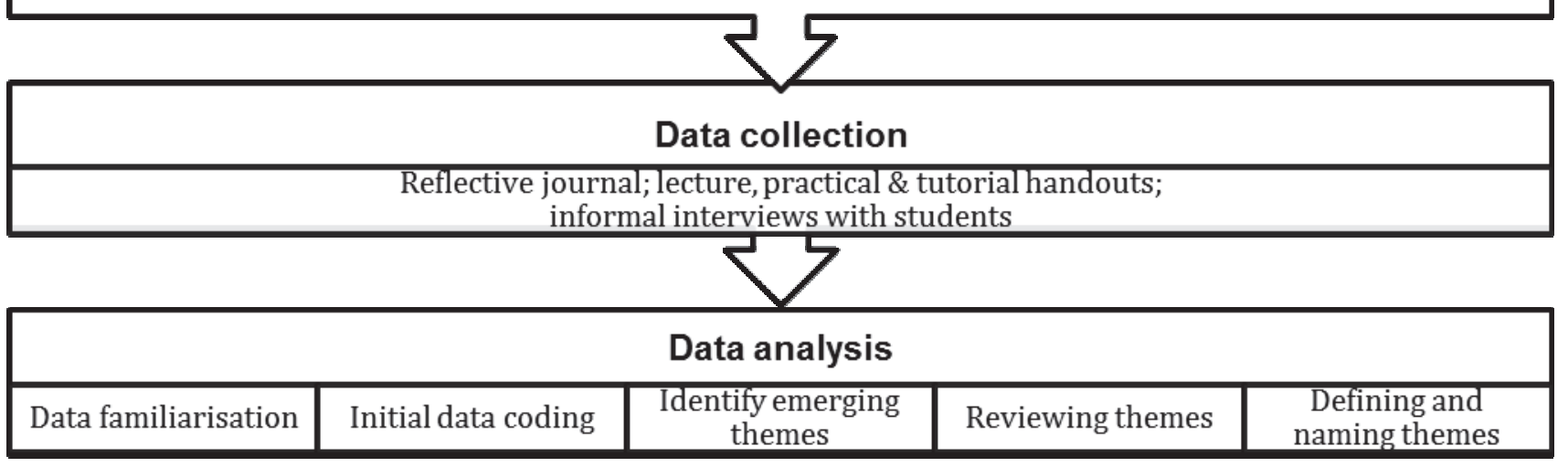

Figure 1. Overview of study design

of the semester (after mid-semester assessments); all lectures and classes in the selected week were attended by $\mathrm{CN}$. Figure 1 provides an overview of the study design.

The study was conducted to provide insight to the realities of the curricular experience and to observe the students' response to this. All of the formal curricular experiences were examined as it has been found that all aspects of professional education (not just the practice related aspects) contribute to students' formation of their professional identities. ${ }^{1,16,19,29}$

\section{Data Collection}

Prior to entering the field all academics and students were informed via email that the study was taking place and when it would occur for each year group. During the observational study, $\mathrm{CN}$ taking an observer-participant stance sat in on lectures, attended tutorials (e.g. listened to student discussions around tutorial questions) and participated in laboratory practicals (e.g. helped weigh out materials for experiments). This enabled an 'insider' perspective. In total, 75 hours of the formal curriculum delivery were observed. Whilst in the field, CN introduced herself to all participants she engaged with and interviewed, described the study and explained who she was (e.g. pharmacist and postgraduate student). Extensive field notes were kept and these described what the students and teachers were doing; the nature and content of the teaching and learning activities; the roles of the students and the 'teachers'; description of the settings and artefacts used during the observation period (e.g. lecture handouts, tutorial materials). Immediately after the observations were completed these notes were written up as field notes to provide a descriptive account of the setting and what had been observed. ${ }^{30}$ During the study a reflective journal was kept by $\mathrm{CN}$, which included insights and interpretations about what was being observed, that is, "speculation, feelings, problems, ideas, hunches, impressions, and prejudices". ${ }^{31}$ Using this approach provided perspectives on the "the world of everyday life as viewed from the standpoint of insiders"32, in our case, the world of the students.
To gain a richer perspective of the student experience and to check the trustworthiness of the observation data, $\mathrm{CN}$ conducted 38 short, informal interviews to triangulate the data. ${ }^{31,33}$ These each lasted approximately 10 minutes and involved asking students for their understandings of the curriculum and whether the observed experiences enabled them to see themselves as pharmacists. The interviews were opportunistic that is, they were conducted with students who $\mathrm{CN}$ sat next to in lectures, and with students who were in CN's tutorial and practical groups. While the interviews were not audio-recorded, notes were taken during the interviews and quotes from the interviews were paraphrased from memory and documented immediately after the interviews.

\section{Participants}

At the time of the study there were 993 students in enrolled in the pharmacy degree and 38 students were interviewed during the study. There were almost twice as many females as males in each year group. The majority of students were Australian residents $(78 \%)$ and the remainder came from South East Asia (17\%), North America (2\%) and other countries $(2 \%)$.

\section{Data analysis}

Data were analysed thematically using the framework method described by Spencer and Ritchie. ${ }^{34}$ A coding framework was developed by drawing on a priori issues gleaned from other studies, the theoretical literature on professional identity formation and sociocultural learning theory (See Table 1). 1,15,16

Table 1 outlines the coding framework. Four key opportunities for student professional identity formation were used to structure the thematic framework. These were: imagination, observation, experimentation and evaluation. ${ }^{1}$ Imagination was understood to be enhanced when students were presented with situations where they could realistically imagine how their learning related to their future pharmacist selves. For example, modelling thinking - how they approach a problem. Observation represented opportunities for students 


\begin{tabular}{|c|c|}
\hline Theme & Sub-theme \\
\hline \multirow[t]{2}{*}{ Imagination } & $\begin{array}{ll}\text { Able to imagine: } \\
\text { - } \quad \text { Drug or product focussed } \\
\text { - } \quad \text { Disease focussed } \\
\text { - } \quad \text { Patient focussed } \\
\text { - } \quad \text { Career focussed } \\
\text { - } \quad \text { Research focussed }\end{array}$ \\
\hline & Not able to imagine \\
\hline \multirow[t]{4}{*}{ Observation } & Pharmacist role \\
\hline & Researcher role \\
\hline & Educator role \\
\hline & Student peers \\
\hline \multirow[t]{2}{*}{ Experimentation } & Drug-focussed \\
\hline & Patient-focussed \\
\hline \multirow[t]{2}{*}{ Evaluation } & $\begin{array}{l}\text { Student self-evaluation: } \\
\text { - } \quad \text { Agree } \\
\text { - } \quad \text { Disagree }\end{array}$ \\
\hline & $\begin{array}{l}\text { External Evaluation } \\
\text { - } \quad \text { Feedback from others }\end{array}$ \\
\hline
\end{tabular}

to observe practitioners or teaching/academic staff engaging in aspects of pharmacy practice or approximations of practice. Experimentation encompassed opportunities for students to try out being a pharmacist in practice or approximations of practice. Finally, evaluation represented opportunities to receive feedback from others or when students were prompted to consider the implications of their learning as it related to their future pharmacist selves.

The data, including field notes, reflective journal, interview notes and curricular artefacts were coded and tabulated by $\mathrm{CN}$ based on the thematic framework using Microsoft Excel. The coinvestigators reviewed the tabulated and coded data; discrepancies on meaning were resolved through discussion. ${ }^{35}$

\section{Ethical Considerations}

Permission to conduct the study was sought, and gained, from the Head of School of Pharmacy at the selected University. Ethical clearance was gained from the School's Ethics Committee before commencing the study. The approval number was 2010/12. During this study CN was a part-time academic teaching into the post-graduate clinical pharmacy program but was not involved in the undergraduate program. Thus $\mathrm{CN}$ was unlikely to be seen as someone who would influence the students' learning or assessment outcomes. Prior to entering the field, teaching staff and students were notified by email of the research project and that $\mathrm{CN}$ would be attending lectures, tutorials and practicals. They were assured that their teaching, studies and assessments would not be affected.

\section{RESULTS}

The results are presented in two sections. The first section provides a descriptive account of the setting to provide insight to the social context of the curriculum. The second section outlines the key themes generated from our analysis.

\section{Setting the scene}

There were three main settings for the formal learning activities - lecture theatres, tutorial rooms and laboratories. This was consistent across all four of the year levels with variation seen in the content delivered rather than the approach to teaching. Lectures dominated the curriculum; followed by tutorials and practicals (see Table 2).

Lectures: Lectures were the main form of teaching for all courses. Students were provided with the lecture notes - primarily PowerPoint slides - before the lecture, via Blackboard $\circledast$, and made notes on these throughout the lecture. The lecturers worked through the PowerPoint slides by reading the information, providing descriptions and explanations about the content on the slides. Attempts to engage the students primarily took the form of questioning and these required the students to recall facts and information from previous lectures or years.

Tutorials: The QUM and social pharmacy streams used tutorials to support the lectures. Students were expected to work through questions in small groups during the tutorial with discussions around how the questions should be answered occurring at the end of the tutorial. Discussions were tutor led. In the QUM subjects, students were also expected to dispense a prescription and a only a few of the students were asked to role-play counselling a patient about their medicines.

Laboratory based practicals: The science-based subjects used laboratory-based practicals to support learning. To conform to workplace health and safety requirements students were required to don laboratory coats, safety glasses, gloves and wear enclosed toe shoes in the laboratories. They would complete the practical, in groups, as outlined by a practical manual. The students were expected to prepare for the practical by answering questions in their practical manual. Tutors were available to help the students with any problems they encountered.

PASS tutorials: Peer Assisted Study Sessions (PASS) tutorials occurred only in the first year of the science courses, that is, biology and chemistry. They were voluntary and run by second and third year students.

Computer based activities: There were two occasions, in the first year mathematics subject and in the fourth year pharmacokinetics subject, where the tutorials were computer based. That is, students were expected to work through problems, e.g.

\begin{tabular}{|c|c|c|c|c|c|}
\hline Table 2. Teaching approaches \\
\hline Teaching approach & Year 1 & Year 2 & Year 3 & Year 4 & Total \\
\hline Lectures (Hours) & 10 & 10 & 10 & 10 & 40 hours \\
\hline Tutorials (Hours) & 5 & 6 & 4 & 5 & 20 hours \\
\hline Practicals (Hours) & 3 & 2 & 3 & 7 & 15 hours \\
\hline Total & 18 & 18 & 17 & 22 & 75 hours \\
\hline
\end{tabular}




\begin{tabular}{|c|c|}
\hline Content area & Example from data \\
\hline Drugs & $\begin{array}{l}\text { "In this lecture, the lecturer provided technical information on how to prepare liquid dosage } \\
\text { forms." (Field notes }-2 \text { nd year) } \\
\text { "This lecture was about the structure activity relationships of antihypertensives using } \\
\text { angiotensin II inhibitors as an example." (Field notes }-3^{\text {rd }} \text { year) }\end{array}$ \\
\hline Disease and physiology & $\begin{array}{l}\text { "This session was run by a tutor who works at the neurology dept at the [hospital name]. For } \\
\text { the first part of the session the students were shown a video of a man who had Parkinson's } \\
\text { Disease - it presented his journey with Parkinson's Disease." (Field notes }-2^{\text {nd }} \text { year) }\end{array}$ \\
\hline Patient & $\begin{array}{l}\text { Theory was linked with practice though a case study, that is, "A } 45 \text { year female old patient } \\
\text { presents with febrile neutropenia (neutrophil count }=700 / \mathrm{ml} \text { ). The patient has recently } \\
\text { received chemotherapy for treatment of breast cancer }- \text { and has chemotherapy-induced } \\
\text { neutropenia - Weight }=60 \mathrm{~kg} \text {, height }=167 \mathrm{~cm} \text {, serum creatinine }=0.09 \mathrm{mM} \text { ( lecture notes } 4^{\text {th }} \\
\text { year) }\end{array}$ \\
\hline Career & $\begin{array}{l}\text { "The next lecture was on pharmacy careers and the lecturer started by saying that 'pharmacy } \\
\text { is a knowledge based profession'. The lecturer described the different areas and fields which } \\
\text { pharmacists could go into." (Field notes }-1^{\text {st }} \text { year) }\end{array}$ \\
\hline Research & $\begin{array}{l}\text { "During this tutorial session the students presented their research findings from their } \\
\text { experiential placements." (Field notes }-4^{\text {th }} \text { year) }\end{array}$ \\
\hline
\end{tabular}

statistical problems, or using particular software, on a computer. These activities were either done individually or in collaboration with peers.

Blackboard®: All of the courses were supported by an electronic learning management system, Blackboard $\AA$, which provided information about the course e.g. aims and objectives, resources (including lecture notes), discussion boards, quizzes and information about the assessment tasks.

\section{Key Themes}

The key themes were based on the a priori framework for student professional identity formation: 1) Opportunities to imagine being a pharmacist; 2) Observing what it might be like to be a pharmacist; 3) Experimenting with being a pharmacist and 4) Evaluating the experience of being a pharmacist. The extent to which these themes were observed in the curricular experience is presented. This is also illustrated using quotes from the interviews and excerpts from the field notes or reflective diary.

\section{Opportunities to imagine being a pharmacist}

The observed curricular experience provided students with several situations to imagine what it might be like to be a pharmacist. Firstly, the content presented in lectures related to the pharmacist role. In particular, there were five different content areas and these included (in order of frequency of occurrence): 1) drugs, 2) disease, 3) patient, 4) career and 5) research (See Table 3). Thus, the content matter could be interpreted to be suggesting to the students that as becoming pharmacists their focus would be on drugs in preference to patients/clients. There tended to be more situations where students might imagine being a pharmacist in third and fourth year because the content was more pharmacy oriented, than in first and second year where there were more generic science subjects.

Secondly, the nature of some of the learning activities was likely to assist students to imagine their future pharmacist role as they mirrored the processes and ways of doing pharmacist-related activities. This was observed during tutorials where students completed questions around case studies, which provided a structure for students to approach particular clinical situations, and in laboratory practicals where they prepared extemporaneous products. For example:

Each group was allocated a case and told that they would have about an hour to do the case study and then they would have some roleplays after that. My group was given the case where a child was teething. As they worked through the case study they discussed what they thought would be the points for referral. In this case, they thought it would be fever.

(Field notes - 2nd year)

The other opportunities for enabling students to imagine being a pharmacist came when the academics or tutors described how they would approach a problem or described their own experiences as pharmacists. From this scenario students were gaining insight to how experienced practitioners would approach problems in practice. For example:

The lecturer described the thinking process which you might go through when handling a poisons call e.g., a nine year-old child [less likely to poison self] swallowing paracetamol, then this might point to another condition e.g. autism; so students need to consider things which are abnormal. A lot of stories were told about the lecturer's experience in answering poison calls. (Field notes -4 th year)

This only occurred three times during the observational study (most of the lecturers were not pharmacists).

There were very few observed instances where explicit connections between the content being presented and practice were made. This meant that when presented with new content, commonly in the form of decontextualised and factual knowledge, it was left to the students to imagine how the content related to being a pharmacist. The student interviews suggested that in a number of instances they struggled to establish meaning from the presented content. The following field data demonstrate this:

During this lecture, the concept of dialysis was presented, that is, how dialysis works. However the role of the pharmacist was not explored and discussions after the lecture 
with the students indicated that as a result of this lecture they would "just have to rote learn everything that was presented". (Field notes 3rd year)

Another factor potentially hampering imagination was when the content or experience (e.g. Laboratory practicals) was related to other roles. For example, there were a number of instances where the academics made connections between the content and other professions, such as, pharmaceutical scientists, medicinal chemists, chemists and scientists. These connections tended to correspond to the educator's background or research interest.

References in this lecture were made to pharmaceutical scientists and the issues, from the lecture content, they would encounter with peptide delivery. (Field notes -4 th year)

Observing what it might be like to be a pharmacist

During the study, students tended to observe the academics and tutors in 'educator roles' rather than enacting pharmacist roles. The only instance where the pharmacist role was enacted was when students' role-played being pharmacists in the tutorials.

Another reason for limited opportunities to observe pharmacists was that, during the study period, there was a dominance of lectures using didactic methods and the students appeared to spend most of their time observing the academics lecturing. For example, the academics enacted an educator role where they explained and presented concepts, content and ideas and different strategies (e.g. questioning, response clickers) were used to promote student learning:

The lecturer explained the concepts and when she presented the clicker questions she encouraged the students to discuss the questions in their groups. For the first question only $36 \%$ of the students answered correctly. The lecturer then described why this answer was correct. (Field notes - 2nd year)

Whilst, practising pharmacists facilitated the dispensing and counselling tutorials, in this study, they adopted the role of educators, for example, working through questions and providing answers. However, students were not observing these pharmacists as their pharmacist selves, modelling their professional thinking and decision-making related to practice-based problems or role-playing patient counselling or interactions but rather were presenting themselves as academics. In some instances the tutors shared their practice experiences or gave them tips about how they might approach problems in practice, but students were largely left to imagine what the pharmacists' role might be like or how the tutors might practice. For example, none of the tutors demonstrated how they might counsel in practice; instead students were asked to do this.

The only time students were able to observe the enactment of being a pharmacist was when their peers demonstrated patient counselling:
"For this tutorial, the students were required to answer the questions outlined in the tutorial manual. The tutors gave the students prescriptions and a patient history and asked the students to take a drug history from each other and to check the prescription." (Field notes - 3rd year)

Whilst there is some value in observing novices, for successful identity formation, expert role models, that is, experienced practitioners who are working in practice, are needed. ${ }^{1}$ Overall, there were few instances during the observational period, where students observed the modelling of pharmacist behaviours and as a consequence there were missed opportunities for students to determine what it is that constitutes successful ways of being a pharmacist. ${ }^{1,13}$

\section{Experimenting with being a pharmacist}

The key opportunities for students to experiment with their professional identities occurred during tutorials and laboratory practicals. Each of these promoted different aspects of practice and these included patient-focussed activities (e.g. counselling; working on case studies) and drugfocussed activities (e.g. preparation of extemporaneous products).

Experimentation with patient-centred pharmacist activities occurred during the two hour per week dispensing and counselling tutorials. These tutorials had the closest resemblance to a practice setting when compared to the other observed aspects of the formal curriculum. During the tutorials, students worked through a case, took a history (with their peers playing the 'patient' role), dispensed medications and prepared for a counselling roleplay. Due to the large student numbers and time limits, only one or two students participated in the role-play with a peer acting as the 'patient' and the tutor provided some feedback. This meant that the other students were left to observe the role-play:

"The students who weren't participating in the role-play (only two students performed the role-play) were asked by the tutor to provide feedback. However, rather than providing feedback those watching tended to take lots of notes on what the tutor was saying." (Field notes -2 nd year)

Despite the intended patient-centeredness of these activities there was an absence of patients, in particular, when the students role-played being patients they lacked authenticity. This approach encouraged information provision rather than patient engagement and there was a focus on the assessment checklist:

Following the role-play the discussion was mainly about the marking criteria - raised by one of the student markers - the role-play 'pharmacist' hadn't asked about patient weight. The tutor suggested that asking about weight is really only necessary for children but is in the marking criteria - 'more for completeness'. (Field notes - 2nd year) 
This meant there was a lack of affordance in the student's experimentation, in that, students were not able to develop their own way of doing things. As a result, the observed ways students engaged with the counselling and dispensing tutorials tended to be mechanistic. For example:

The first part of the tutorial the students were given a piece of paper with the patient history from the tutor. In pairs or groups of three the students had to take a history, as if they were a pharmacist from their peer who had the information sheet. Once they'd received the sheet the students just 'got into it'...they didn't seem to take time to read the sheet or consider what needed to be done. It almost seemed as though they were just going through the motions. (Field notes - 3rd year)

The time when all of the students appeared most actively engaged and able to experiment with pharmacist-related activities was during the laboratory practicals. More time was devoted to these practicals (three hours per week) than counselling tutorials (two hours per week). During these practicals students worked in small groups and were required to compound products (e.g. Spironolactone suspension) using real artefacts and completed a laboratory report that was assessed. Students worked through the steps provided in the laboratory manual. For example:

1. "Weigh/measure the appropriate quantity of each component.

2. Triturate (mix) any powders and the suspending agent in a mortar using geometric progress to ensure complete mixing." (Course material - 2nd year)

Despite the authenticity the students' response to the activity was often not congruent with the intention, in that, they appeared to distance their engagement. For example:

One of the girls told me this morning that "once everyone has done all the [extemporaneous] products, that is, after week one, they just share all of their notes and formulas with each other so they don't have to worry about working it out for themselves. (Informal interview - 3rd year)

The student response may have been due to their understanding and experiences of contemporary pharmacy practice, in that, pharmacists are now infrequently required to prepare extemporaneous products and thus the laboratory experience was not connecting with how they saw their future pharmacist selves.

Throughout the observational study, students' engagement with the curriculum tended to be dependent on the relationship of the learning activities to the assessment. For example, very few students attended a lecture at times when they had other assessments due or when they believed that the content was not going to be assessed:

"At least half to the students left after the previous lecture. Talking to the students behind me it seemed that they didn't stay because the materials weren't assessable." (Field notes -4 th year)

This occurred a number of times during the study and across all year groups.

This way of engaging with the curricular experience was reinforced by the academics, in that, academics tended to promote a focus on assessment tasks e.g. students were asked by academics to recall facts rather than discuss ideas, rather than making connections with practice. In particular students were directed to remember content:

"At 9:40 the lecturer made a reference to the assessment and said that there will be MCQs and the students need to recognise which ones [drug structures] are 'active' but they don't need to be able to draw them." (Field notes - 3rd year)

As a result, the majority of the students felt they needed to respond to the curricular experience by memorising and rote learning content:

I chatted to the students who were sitting near me. I asked them what they would do with these materials from the lecture? They said that they would cram it all in before the exam, check through past papers and work out what they [the lecturers] focus on and memorise the past paper answers. (Informal interview 4th year)

This focus on assessment was encouraged by the academics. On numerous occasions throughout the study the students were directed by the academics to what they needed to know or remember for their assessments. The language used implied that the content presented was absolute and thus students' engagement was limited to remembering.

"The important points were emphasised by the lecturer and the students were told what to remember, e.g. 'put a box around this...'; 'what I want you to really know.....'; 'I want you to remember this....'; 'this is important....'. (Field notes - 3rd year)

Rather than presenting the curricular experience as an opportunity to experiment with provisional pharmacist identities, the direction towards assessment seemed to reinforce student identities and provided limited opportunities to experiment with being pharmacists. The student response was that they perceived that what was presented needed to be remembered:

"One of the slides contained a huge amount of information and the students groaned when it was put up. The student next to me complained about how much information was being presented and stated 'how are we going to remember it all'. There were 102 slides for this 2 hour lecture." (Field notes and informal interview -2 nd year) 


\section{Evaluating the experience of being a pharmacist}

Students were rarely prompted to examine how their learning experiences related to their future pharmacist selves. In other words, they were not asked to consider what kind of pharmacist they would like to be neither were they challenged about the kind of pharmacist they thought they were becoming. This meant that the students needed to establish meaning from the curricular experiences and relate these to becoming a pharmacist in isolation. The interviews with some of the students suggested that they found this difficult and/or they dismissed the learning experiences as not being relevant. For example, the students, in the main felt that most of the content was interesting and complex and the assessment tasks were challenging, however they often indicated that they could not see how these learning experiences related to their future selves:

"One student commented that she felt that they needed the background knowledge and if they didn't have that then it would be just a 2 year degree not a 4 year degree." (Field notes 4th year)

"I was talking to the students before the practical where they had to develop a formulation e.g., tablets, suspension, gel, ointment. One of the male students commented that he didn't think he was ever going to use this 'stuff' again." (Field notes and informal interview -4 th year)

In a number of instances, students were upset that they could not see how what they were learning related to their future roles. Thus perceiving that there was a lack of congruence between who they consider themselves to be, the curricular portrayal of the pharmacist role and the realities of practice:

One male student reported finding the content really interesting but stated that he was bitterly disappointed that he couldn't foresee ever being able to use this information when practicing as a pharmacist. (4th year - field notes)

In terms of external evaluation of students' professional identities, during the observational period, there were very few opportunities for students to receive feedback on what they had done and the activities in which they had participated. Instead students tended to discuss ideas amongst themselves:

Most of the students hadn't prepared for the dispensing and counselling tutorial beforehand. Their first reference source was Wikipedia. This gave them information about the symptoms of teething and different treatments which can be used. The students were given no guidance on resources and they said that they usually used Google $®$. (Field notes - 2nd year)

There was only one instance where students received feedback on their performance as pharmacists. This occurred in the second year where students received some feedback on their role-played counselling but due to time constraints and large student numbers the feedback was limited. For example:

The tutor provided feedback on each of the role-plays - 'that was good'. While the tutor provided some specific feedback e.g. fever as a referral point, or looking at the patient's ankle, I felt that there were other aspects which needed to be worked through e.g. students in the role play were using phrases like 'you'll get GI effects'; 'this might make you nauseous but that'll be OK' - however the forum didn't lend itself to this. (Field notes 2nd year)

Also, this feedback was only directed to the two students who participated in the role-play.

Finally, when students did receive feedback, in all of the student year groups this tended to be related to their performance in their assessments. For example, needing to adhere to the counselling assessment checklist or their performance in examinations. The following quote demonstrates this:

"For the first half an hour of this lecture the students were provided with feedback on their assignments. The lecturer has marked all of the assignments and provided the students with extensive feedback. The students were shown how to find their grades on blackboard via screen shots." (Field notes - 2nd year)

\section{DISCUSSION}

This study begins to address an important gap in pharmacy practice and education research: an examination of what opportunities exist in the formal pharmacy curriculum for students to form their identities as pharmacists. A qualitative ethnographic approach was used to examine opportunities for professional identity formation because identity formation is sociocultural in nature, that is, it is formed through observing role models, interacting with people and participating in activities. ${ }^{16,36}$ Five key findings, related to the influence of the formal curriculum experience on students' professional identity formation, were identified: 1) the drug focused nature of curricular experience; 2) few connections being made to practice; 3) limited opportunities to observe pharmacist role models; 4) opportunities needed to experiment with being a pharmacist; 5) creating space in the curriculum for students to evaluate professional identities. Overall, from the perspective of professional identity formation, the curriculum may not be enabling students to construct strong patient-centred professional identities. This discussion will examine aspects of the curricular experience and make suggestions for how the pharmacy curriculum may best support student professional identity formation.

\section{Becoming a drug-focused pharmacist?}

The drug-focused nature of the curricular experience in conjunction with limited patient interactions was an important finding for this study. 
Pharmacists are aspiring to being patient-centred health care professionals ${ }^{37,38}$ and recent research highlights the need for curricula to be patient focused. ${ }^{39}$ However, the experiences being offered in the observed curriculum meant that students were likely to be forming their professional identities with limited participation in patient-focussed learning activities. The consequence of this is that there may be uncertainty in students' professional identities as they relate to patients. ${ }^{40}$ These findings may begin to explain the role ambiguity described by pharmacy students $^{41}$ and the weak professional identities of pharmacy students observed by Taylor and Harding. ${ }^{2}$ For example, role ambiguity and weak professional identities may result when the curricular experience commences with a scientific focus and offers limited engagement with patients despite the profession's philosophy of practice, pharmaceutical care, suggesting otherwise.

There are few examples of pharmacy educators engaging patients in curriculum design. ${ }^{43}$ Medicine has recognised the importance of placing patients at the centre of its curriculum as a means of fostering professional identity formation and has sought guidance from patients when designing their curricula. ${ }^{40,44}$ In this study, opportunities for students to begin to see themselves as pharmacists in relation to the patient rather than in relation to an assessment criteria or an academic or a peer were limited to observing peers role-playing counselling or participating in role play. Formation of professional identities in relation to patients requires more than the subject matter to be about patients, it also requires active engagement and interaction. ${ }^{40}$ One UK study examining patients' perceptions of their engagement in pharmacy education has found that patients found this to be a positive experience. $^{45}$ Thus educators should consider enabling meaningful interactions with patients in the context of the formal curriculum. This might be achieved through the inclusion of simulations, actors or real-life patients where the students are able to enact their pharmacist role. Experiences such as these will enable students to construct their professional identities with a clear understanding of their role as it relates to patient care.

\section{Making connections to practice}

Another important finding from this study was the lack of connections between the content being presented and how it relates to the students' future practice. As a result, students were left to make the connections themselves. This has important implications for professional identity formation. For example, Reid et al. ${ }^{17}$ in a large international study examining professional identity formation over a range of professions found that when connections are not made to future practice, students tend to have a narrow view of their future profession.

In other words, the risk for pharmacy students is that they may have a limited view of what it might be to be a pharmacist. Our findings suggest that students were disclaiming those subjects where they could not see the connections. Examination of how pharmacy curriculum makes connections to practice warrants further exploration. However, strategies for improving the connection between curriculum content and practice have been suggested. ${ }^{46}$ The authors suggest integrating disciplines which have previously been separated (e.g. pharmacology, medicinal chemistry, biochemistry, pathophysiology and anatomy) and teaming academics together e.g. science with practice. This approach would enable a more authentic presentation of knowledge as it is used in practice and by solving problems by drawing on knowledge from a number of disciplines (e.g. supporting a patient with swallowing difficulties by drawing on knowledge about pharmaceutics and pharmacotherapeutics). Such an approach would assist students to imagine, that is, make connections with who they're becoming.

\section{Pharmacist role models}

Role models play a significant part in validating students' professional identity and conversely, the absence of positive role models results in naïve professional identity formation.,10 These role models however needed to demonstrate their approach to professional practice as well as acting as educators. Although other studies have found that pharmacy students see their educators as important role models, especially those who practice $^{18}$, this study furthered our understanding of how role models might be utilised to make positive contributions to students' professional identity formation. That is, pharmacy educators, as well as describing their experiences in practice, need to be 'enacting the pharmacist role' for students to observe.

Whilst this finding is not unique to pharmacy ${ }^{1}$, it focuses educators' attention on the importance of incorporating a range of pharmacist role models into the formal curriculum. In particular, there is a need to select pharmacist role models who enact the aspired patient-centeredness of the profession by demonstrating how they would interact with patients. Also, practising pharmacists who tutor need to be supported in their role to develop strategies to best enact their professional selves in the context of the formal curriculum, for example, by engaging in a live role-play. ${ }^{19}$

\section{Fostering opportunities to experiment}

This study found that significant periods of curriculum time were spent by students listening to lectures and in particular, lectures that provided theoretical, decontextualized knowledge. A curricular experience such as this hampers opportunities for student participation and thus hampers experimentation and opportunities to validate professional identities. ${ }^{16}$ The implication of this is that students are likely to be learning about practice rather than having opportunities to validate their professional identities through 'actual engagement' or participation in practice. ${ }^{13}$ Moreover, students are likely to be reliant on experiential placements for opportunities to shape their professional identities.

The risk, for an emerging profession, is that students will accept practice as is and position their professional identities in relation to current practice. 
There is evidence, examining the experiences of newly qualified pharmacists, which suggests that pharmacy practice, as an emerging profession, does not consistently support patient-centred opportunities and as a result new pharmacists can be left disenchanted. ${ }^{8}$ However, if educators seek to foster strong professional identities in the curriculum, where students have a clear sense of themselves and an understanding of what they might encounter in practice, they will be more likely to cope with the experiences and maintain as sense of professional self. ${ }^{1}$ One strategy educators might use is to promote dialogue about what it means to be a pharmacist within teaching and learning activities and to foster collaboration with peers and experts where the objective is to promote interaction and discussion. ${ }^{19,20}$

Whilst it could be argued that the purpose of the experiential placements is to provide opportunities to experiment with being a pharmacist, the nature of experiential placements can be problematic, in that, the experience may lack congruence with university teaching or the workplace may not consistently allow students to enact their pharmacist roles. ${ }^{1,47} \mathrm{An}$ excellent example, how pharmacy educators might create opportunities for students to experiment with their professional identities is the "model pharmaceutical education centre" implemented in the US. ${ }^{48}$ This centre was designed to provide pharmaceutical care however, this care is provided by students under the supervision of pharmacists and academic staff. The experience enabled students to be actively engaged by working with experienced pharmacists and academics, in patient care activities including anticoagulant monitoring, diabetes self-management and cholesterol management.

\section{Supporting identity formation through feedback}

Findings from this study suggest that during the formal curriculum there were few opportunities for students to receive feedback, thus students' professional identities were not being corroborated or validated. Several studies have shown that successful professional identities are formed when feedback is received from others in the profession. ${ }^{1,15,22}$ This feedback needs to be facilitative and reflective, that is, it needs to enable students to examine who they are becoming rather than just focusing on assessment. A further implication is that students will be unable to establish how others see them as pharmacists. ${ }^{1}$ Thus, opportunities need to be created in the curriculum experience to provide meaningful feedback on the students' pharmacist enactments.

Internal evaluation is also important aspect in enabling students' to construct their professional identities. ${ }^{1,15}$ There was limited evidence of this occurring in this study. Thus one strategy might be through the use of parallel charts. ${ }^{49,50}$ These charts require students to write about their professional experiences, how they contribute to patient care and what this means for them as becoming professionals. Results from one study suggested that using parallel charts could be an effective way to create pedagogical spaces for students to develop their own professional identities. ${ }^{51}$

\section{Lessons for pharmacy educators}

An important finding for pharmacy educators is that the intended curriculum experience may not be representative of the learning that results from the student curricular experience. In other words, what is taught does not always equate with what is learnt. Whilst this has been identified as a significant issue in medicine and referred to as the 'hidden curriculum $^{, 52-55}$ there is limited research on this within pharmacy education.

The challenge for educators, Wenger ${ }^{16}$ argues, is that what emerges as the curriculum experience needs to be recognised and responded to. For example, an academic may plan an interactive and engaging tutorial on how to communicate with a patient, however, the response from the students indicates that their key concern is whether they are going to be assessed on the materials rather than how they might communicate with their future patients. This practice of focusing on assessment may have emerged from the design of the curriculum or from the expectations of the students. Thus, considerations might focus on changing the assessment type from one focused on assessing knowledge to one that examines behaviour or prompting students to a patient-centred approach within the tutorial.

\section{Limitations}

Whilst this study provides unique insight to the student experience of the curriculum and its influence on professional identity formation, the findings of this study may not be completely generalizable. Firstly, the findings from this study, as with most ethnographic studies, are based on the perspective of one pharmacist researcher. Whilst we attempted to assure quality through the triangulation of data collection and coder agreement in the data analysis, there would have been value in receiving respondent validation from the students and academics. Secondly, the study was conducted within one School of Pharmacy and may not be representative of other Schools. It would be valuable to conduct this study in other Schools. Thirdly, the interviews were opportunistic and thus there would have been value in conducting in-depth student interviews and to have purposively sampled the students. Also, the interviews were not audiorecorded and the recorded quotes may have been influenced by recall bias. Further research will be conducted to examine the students' perceptions in more detail. Fourthly, the researcher's presence in the field may have influenced the participants. This could not be controlled. Finally, spending one week in each year group may be seen as a limitation. However, the four week block allowed a level of immersion in the student experience and a time to consolidate, review and revise observations that is uncommon in studies of this type. Moreover, given the rich descriptions of the learning context the findings provide a basis for professional and pharmacy educators to work from. ${ }^{56}$ 


\section{CONCLUSIONS}

The examination of a curriculum identity forming project has provided new insights as to how the curriculum experience attends to identity formation. The study also highlights opportunities for pharmacy educators to begin to explicitly address professional identity formation. In particular, the findings of this study challenge pharmacy educators to consider how the pedagogy and curriculum structure promote patient-centeredness, make connections to practice, enable pharmacist role models and create opportunities to experiment and foster a curriculum which supports feedback.

\section{CONFLICT OF INTEREST}

None declared.

\section{CONVIRTIÉNDOSE EN UN FARMACÉUTICO: EL PAPEL DEL CURRÍCULO EN LA FORMACIÓN DE LA IDENTIDAD PROFESIONAL}

\section{RESUMEN}

Objetivo: Entender como la experiencia del currículo formar de un curso australiano de pregrado de farmacia apoya la formación de identidad profesional. Métodos: Se realizó un estudio cualitativo etnográfico durante cuatro semanas usando la observación de los participantes y se examinó la experiencia del 'típico' estudiante desde la perspectiva de un farmacéutico. Se mantuvo un periodo de una semana de observación para cada uno de los grupos de los cuatro años (esto es, para los cursos de primero a cuarto) que componen el currículo de pregrado. Se recogieron los datos a través de observación de la experiencia formal del currículo usando notas de campo, un cuaderno de reflexión y entrevistas informales con 38 estudiantes de farmacia. Se analizaron los datos temáticamente usando un marco analítico a priori.

Resultados: Nuestros hallazgos mostraron que el currículo observado era una experiencia curricular convencional que se centraba en la provisión de conocimientos técnicos y proporcionaba algunas opciones de enlace con la práctica. Existían algunas oportunidades para que los estudiantes se imaginasen a sí mismos como farmacéuticos, por ejemplo cuando el contenido de las clases estaba relacionado con la práctica o cuando el personal docente describía su abordaje de problemas prácticos. Sin embargo, hubo escasas oportunidades para que los estudiantes observaran modelos del papel del farmacéutico, experimentasen siendo farmacéuticos o evaluasen sus identidades profesionales. Aunque había actividades de aprendizaje curricular para que los estudiantes desarrollasen como farmacéuticos, p.e. consejo a pacientes, no había contacto con pacientes y el personal docente tendía a actuar como educadores con poca evidencia de ellos mismos como farmacéuticos.

Conclusión: Estos hallazgos sugieren que el abordaje actual convencional del diseño del currículo puede no ser capaz de capacitar experiencias de aprendizaje que apoyen a los estudiantes en la adquisición de sus identidades profesionales con éxito. Por el contrario, parecía reforzar sus identidades como estudiantes con una comprensión naif de la práctica profesional, dificultando su transición al futuro ejercicio profesional.

Palabras clave: Estudiantes de Farmacia; Ejercicio Profesional; Papel Profesional; Currículo; Desarrollo de programa; Investigación Cualitativa; Australia

\section{References}

1. Ronfeldt M, Grossman P. Becoming a professional: experimenting with possible selves. Teacher Educ Q. 2008; 35(3):41-60.

2. Reid A, Abrandt Dahlgren M, Dahlgren LO, Petocz $P$, Dahlgren MA. How is professional identity developed? from expert student to novice professional. In: Vol 99 Professional identity. Netherlands; Springer; 2011. ISBN 978-94-0070250-9

3. Bleakley A, Bligh J, Browne J, eds. Medical education for the future: identity, power and location. Dordrecht: Springer Netherlands; 2011

4. Wledenmayer K, Summers R, Mackle C, Gous A, Everard M. Developing pharmacy practice: A focus on patient care. Geneva: WHO \& FIP; 2006

5. Elvey R, Hassell K, Hall J. Who do you think you are? Pharmacists' perceptions of their professional identity. Int $J$ Pharm Pract. 2013;21(5):322-332. doi: 10.1111/ijpp.12019

6. Airley R. Are pharmacists considered scientists or clinicians? An undergraduate project. Pharm J. 2013;290:716.

7. Willis SC, Shann P, Hassell K. Pharmacy career deciding: Making choice a "good fit". J Health Organ Manag. 2009;23(1):85-102

8. Eden M, Schafheutle El, Hassell K. Workload pressure among recently qualified pharmacists: an exploratory study of intentions to leave the profession. Int J Pharm Pract. 2009;17(3):181-187.

9. Cooke M, Irby DM, O'Brien BC. Educating physicians: a call for reform of medical school and residency. Standford: Jossey-Bass; 2010.

10. Goldie J. The formation of professional identity in medical students: Considerations for educators. Med Teach. 2012;34(9):e641-e648. doi: 10.3109/0142159X.2012.687476

11. Johnson M, Cowin LS, Wilson I, Young H. Professional identity and nursing: contemporary theoretical developments and future research challenges. Int Nurs Rev. 2012;59(4):562-569. doi: 10.1111/j.1466-7657.2012.01013.x

12. Izadinia M. A review of research on student teachers' professional identity. British Educational Research Journal. 2013:39(4):694-713. doi: 10.1080/01411926.2012.679614

13. Scanlon L. "Becoming" a Professional. In: Scanlon L, ed. "Becoming" a Professional. Dordrecht: Springer Netherlands; 2011.

14. Beauchamp C, Thomas L. Understanding teacher identity: an overview of issues in the literature and implications for teacher education. Cambridge Journal of Education. 2009;39(2):175-189. doi: 10.1080/03057640902902252 
15. Ibarra H. Provisional selves: experimenting with image and identity in professional adaptation. Administrative Science Quarterly. 1999;44(4):764-791.

16. Wenger E. Communities of Practice: Learning, meaning and identity. Cambridge: Cambridge University Press; 1998.

17. Reid A, Abrandt Dahlgren M, Dahlgren LO, Petocz P, Dahlgren MA. Professional Pedagogies: what pedagogic approaches can enhance professional learning? In: From Expert Student to Novice Professional. Vol 99: Springer Netherlands; 2011. ISBN: 978-94-007-0249-3

18. Schafheutle EI, Hassell K, Ashcroft DM, Hall J, Harrison S. How do pharmacy students learn professionalism? Int J Pharm Pract. 2012;20(2):118-128. doi: 10.1111/j.2042-7174.2011.00166.x

19. Grossman $P$, Compton C, Igra D, Ronfeldt M, Shahan E, Williamson P. Teaching practice: A cross-professional perspective. The Teachers College Record. 2009;111(9):2055-2100.

20. Sutherland L, Markauskaite L. Examining the role of authenticity in supporting the development of professional identity: an example from teacher education. High Educ. 2012;64(6):747-766. doi: 10.1007/s10734-012-9522-7

21. Hunter L, Rossi T, Tinning R, Flanagan E, Macdonald D. Professional learning places and spaces: the staffroom as a site of beginning teacher induction and transition. Asia-Pacific Journal of Teacher Education. 2011;39(1):33-46.

22. Pratt MG, Rockmann KW, Kaufmann JB. Constructing professional identity: the role of work and identity learning cycles in the customization of identity among medical residents. Acad Manag J. 2006;49(2):235-262.

23. Nyström S. The dynamics of professional identity formation: graduates' transitions from higher education to working life. Vocations and Learning. 2009;2(1):1-18. doi: 10.1007/s12186-008-9014-1

24. Reid A, Dahlgren LO, Petocz P, Dahlgren MA. Identity and engagement for professional formation. Studies in Higher Education. 2008;33(6):729-742.

25. Australian Pharmacy Council. The Australian Pharmacy Council Accreditation Standards Version 1.0. Canberra: Australian Pharmacy Council; 2009.

26. Marriott JL, Nation RL, Roller L, Costelloe M, Galbraith K, Stewart P, Charman WN. Pharmacy education in the context of Australian practice. Am J Pharm Educ. 2008;72(6):131.

27. Australian Government. Commonwealth Grant Scheme funding cluster amounts. In: Department of Industry Innovation Science Research and Tertiary Education, ed. Canberra; 2013.

28. Noble C, O'Brien M, Coombes I, Shaw PN, Nissen L. Concept mapping to evaluate an undergraduate pharmacy curriculum. Am J Pharm Educ. 2011;75(3):55.

29. Trede F, Macklin R, Bridges D. Professional identity development: a review of the higher education literature. Studies in Higher Education. 2012;37(3):365-384. doi: 10.1080/03075079.2010.521237

30. Willims DG. Participant Observation. In: Willims DG, Johnson N, eds. Essentials in Qualitative Research: A Notebook for the Field. 1993.

31. Creswell JW. Research design: Qualitative, quantitative, and mixed methods approaches 3rd ed. Thousand Oaks: SAGE; 2009

32. Jorgensen KMI, Keller HD. The contribution of communities of practice to human resource development: learning as negotiating identity. Advances in Developing Human Resources. 2008;10(4):525-540. doi: 10.1177/1523422308320374

33. Yin RK. Case study research: design and methods. 4th ed. Thousand Oaks, CA: SAGE; 2009.

34. Ritchie J, Spencer L. Qualitative data analysis for applied policy research. In: Bryman A, Burgess R, eds. Analyzing Qualitative Data. London: RoutledgeFalmer; 1994.

35. Silverman D. Doing qualitative research: a practical guide. London: SAGE; 2004.

36. Packer MJ, Goicoechea J. Sociocultural and constructivist theories of learning: ontology, not just epistemology. Educ Psychol. 2000;35(4):227-241.

37. Hepler CD, Strand LM. Opportunities and responsibilities in pharmaceutical care. Am J Hosp Pharm. 1990;47(3):533543.

38. Cipolle R, Strand L, Morley P. Pharmaceutical care practice: the clinician's guide. 2nd ed. New York: McGraw-Hill; 2004.

39. Losinski V. Educating for action: understanding the development of pharmaceutical care practitioners: faculty of the Graduate School, University of Minnesota; 2011.

40. Bleakley A, Bligh J. Students Learning from Patients: Let's Get Real in Medical Education. Adv Health Sci Educ Theory Pract. 2008;13(1):89-107

41. Kritikos V, Watt HMG, Krass I, Sainsbury EJ, Bosnic-Anticevich SZ. Pharmacy students perceptions of their profession relative to other health care professions. Int J Pharm Pract. 2003;11:121-129.

42. Taylor KMG, Harding G. The pharmacy degree: The student experience of professional training. Pharm Educ. 2007;7(1):83-88.

43. Towle A, Bainbridge L, Godolphin W, Katz A, Kline C, Lown B, Madularu I, Solomon P, Thistlethwaite J. Active patient involvement in the education of health professionals. Med Educ. 2010;44(1):64-74. doi: 10.1111/j.13652923.2009.03530.x

44. Bleakley A. The curriculum is dead! Long live the curriculum! Designing an undergraduate medicine and surgery curriculum for the future. Med Teach. 2012;34(7):543-547. doi: 10.3109/0142159X.2012.678424

45. Shah R, Savage I, Kapadia S. Patients' experience of educating pharmacy undergraduate students. Pharm Educ. 2005;5(1):61-67.

46. Austin Z, Duncan-Hewitt W. Faculty, student, and practitioner development within a community of practice. Am J Pharm Educ. 2005;69(3):55.

47. Egan T, Jaye C. Communities of clinical practice: the social organization of clinical learning. Health (London). 2009;13(1):107-125. doi: 10.1177/1363459308097363 
48. Mehta BH. Advancing patient care through innovative practice: The Clinical Partners Program. Am J Health Syst Pharm. 2005;62(23):2501-2507.

49. Charon R. The patient-physician relationship. Narrative medicine: a model for empathy, reflection, profession, and trust. JAMA. 2001;286(15):1897-1902.

50. Clandinin J, Cave MT, Cave A. Narrative reflective practice in medical education for residents: composing shifting identities. Adv Med Educ Pract. 2010;2:1-7. doi: 10.2147/AMEP.S13241

51. Clandinin DJ, Cave MT. Creating pedagogical spaces for developing doctor professional identity. Med Educ. 2008;42(8):765-770. doi: 10.1111/j.1365-2923.2008.03098.x

52. Haidet $P$, Stein $H$. The role of the student-teacher relationship in the formation of physicians. J Gen Intern Med. 2006;21(Suppl 1):S16-S20.

53. D'Eon M, Lear N, Turner M, Jones C; Canadian Association of Medical Education. Perils of the hidden curriculum revisited. Med Teach. 2007;29(4):295-296.

54. Hafferty FW. Beyond curriculum reform: confronting medicine's hidden curriculum. Acad Med. 1998;73(4):403-407.

55. Hafferty FW, Hafler JP. The Hidden Curriculum, Structural Disconnects, and the Socialization of New Professionals. In: Hafler JP, ed. Extraordinary Learning in the Workplace. Innovation and Change in Professional Education. 6: Springer Netherlands; 2011.

56. Lincoln Y, Guba E. Naturalistic Inquiry. Newbury Park, CA: Sage Publications; 1985. 